\title{
Changes in Water-Soluble Nitrogen and Organic Carbon in the Post-Fire Litter Layer of Dahurian Larch Forests
}

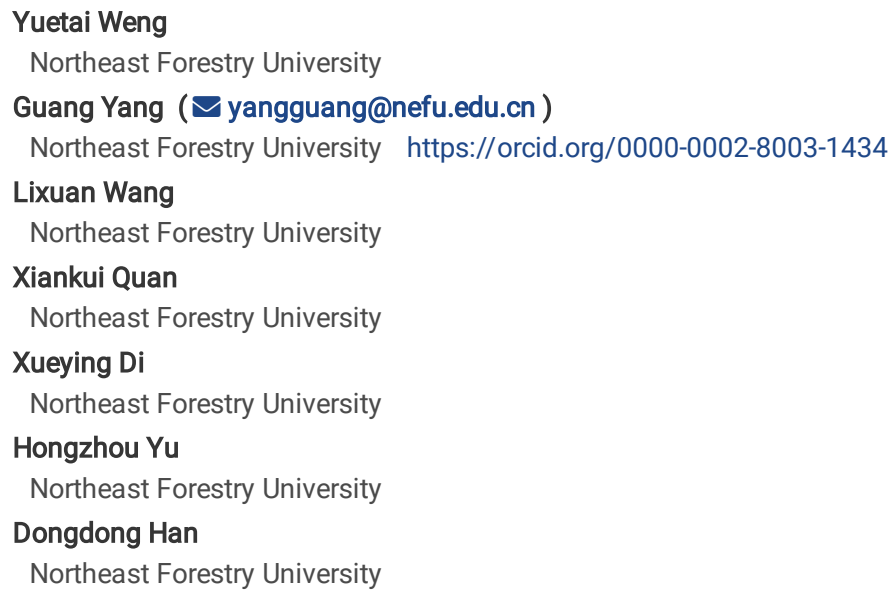

Version of Record: A version of this preprint was published at Plant and Soil on April 14th, 2021. See the published version at https://doi.org/10.1007/s11104021-04934-9. 


\section{Abstract}

Background and aim

Boreal forests account for one third of terrestrial carbon stock. Wildfires are an important perturbation of this carbon pool, affecting in particular the litter layer. After forest fires, the litter layers may possess shifting chemical property and decomposition dynamics due to the changes in post-fire vegetations succession and abiotic factors.

\section{Methods}

We measured water-soluble organic carbon (WSOC) and water-soluble nitrogen (WSN) in the litter layers of Oi and Oe horizons in boreal forests along a gradient of fire history in northeastern China.

Results

We found that WSOC and WSN concentrations in the Oi layer were higher than those in the Oe layer. The concentrations were markedly altered by fires and showed different responses to the ecological succession. The time since fire had significant positive correlations with WSOC in Oi and Oe layers. The distancebased redundancy analysis and the structural equation model analysis suggested that factors additional to the time since fire also influenced the litter watersoluble matter (WSM) properties. Biotic factors were more strongly correlated with the litter WSM properties in the Oe layer than in the Oi layer. Although biotic factors contributed less than abiotic factors to the WSM properties, they still play significant roles in litter WSM in burned area.

\section{Conclusions}

Our results show that manipulating biotic factors can be an important management strategy for litter WSM restoration, which can assist the overall ecological restoration in burned forests faced with the increasing danger of wildfires in the changing global climate.

\section{Introduction}

Global boreal forests store $30-40 \%$ of terrestrial carbon. The world's forest biomes sequester approximately $30 \%$ of global soil organic carbon and $60 \%$ of global carbon (Preston et al., 2006; Scharlemann et al., 2014; Rumpel, 2019). Therefore, boreal forest biomes play a key role in the global ecological system. The litter layer in a forest consists of undecayed to mostly decayed leaves and twigs from the forest canopy. Numerous observational works and litter manipulation experiments have demonstrated that the litter layer is an important forest carbon sink and nutrient source for forest soil. Not only is the litter layer an essential part of nutrient cycling in forest ecosystems, but it also acts as a protective layer by buffering changes in the soil (Sayer, 2006).

Wildfires burn 10-15 million hectares of circumpolar boreal forests annually, representing between approximately 0.2 and $1 \%$ of the total area in different forest regions, and the percentage of burned area is projected to increase significantly by the end of this century (Flannigan et al., 2009). Wildfires are a dominant natural control factor in stand structure and species composition in boreal forests. Stand-replacing fires punctuate the start and end of successional cycles in boreal forests, and the impact of fires on forest stands is expected to be seen for many years as a result of post-fire vegetation succession and remaining ash (Flannigan et al., 2009; Schulze et al., 2012; Bodí et al., 2014). Fires directly or indirectly affect biogeochemical cycles through the recovery of forest stands in succession, long-term changes in the bio-element dynamics of ecosystems, and changes in the chemical composition of the organic matter (Goulden et al., 2011; Walker et al., 2019).

Litter layer development in burned areas results from the interactions between three influencing factors: litter inputs from vegetation, decomposition outputs, and wildfires. The forest litter layer is a buffer for the forest's microclimate, and it is also the major fuel source for wildfires. Forest fires can rapidly alter the litter layer's structure and composition. When the litter layer burns, it is transformed into materials with different chemical and physical properties. These pyrogenic materials possess variable yet distinct characteristics when compared to the unburned litter layer, such as higher recalcitrance and the associated resistance to biological degradation.

After a forest fire, along with the restoration of vegetation and litter fall, the litter layer on the burned forest floor begins to accumulate and gradually cover the forest's surface soil again. The interaction between fire and vegetation leads to the transition cycle from litter layer to ash to post-fire litter layer. While much research has focused on ash and the litter layer, there has been little research on the evolution of the post-fire litter layer. Also, research on the effects of fires on the landscape has paid relatively little attention to the post-fire litter layer until recently (Santin et al., 2016). Compared with the unburned forest litter layer, the lower part of the post-fire litter layer has pyrogenic organic materials, while the upper part is fresher. The upper part of the burned litter layer is the transitional stage between ash and unburned litter layer. During the ecological succession, the physical and chemical properties of the post-fire litter layer also change; therefore, this layer gradually changes its role in the biogeochemical cycle of the burned area.

Water-soluble organic carbon (WSOC) and water-soluble nitrogen (WSN) are important C and N fractions in the biogeochemical cycling of a forest (Neff and Asner, 2001; Tipping et al., 2005), and the content of WSOC and WSN in the litter layer represents a potentially important conversion of organic matter (Froberg et al., 2007). In forest soil, the litter layer is the primary source of water-soluble matter (WSM), and litter layer percolates provide substantial C inputs to the underlying mineral soil (Froberg et al., 2003), thus influencing C stocks and microbial lives as an energy source (Lee et al., 2018). Information on how terrestrial WSM production, transportation, and degradation are altered by wildfires is therefore essential for understanding how climate change might affect landscape and aquatic carbon cycling (Tranvik, 2009).

Most forest fires do not cause complete changes in forests, such as the depletion of forest cover, but they do cause dynamic changes in biomass (Coleman et al., 2008; Vargas et al., 2008). Vegetation biomass is closely related to the restoration of post-fire forest ecosystems and the litter layer; therefore, biomass 
cannot be neglected when considering the changes in the litter layer (Berner et al., 2012). Post-fire vegetative dynamics, especially biomass changes, are drivers of the microbial community structure and function in forest soil (Hart et al., 2005). The forest litter layer is the product of the interactions and activities of vegetation and decomposers, and these interactions and activities are influenced by both the time since fire and geographic space; therefore, the content and characteristics of the litter layer's WSM in the burned area is constantly changing spatiotemporally through the actions of organisms (Handa et al., 2014). Understanding the extent to which each of these factors limits the recovery rate and influences the dynamics of WSM following a wildfire disturbance can aid in the design of burned-area management regimes and, more broadly, contribute to our understanding of WSM dynamics in litter subjected to fire disturbances.

The purpose of this paper is to examine the dynamics of litter layer WSOC and WSN along a chronosequence in post-fire boreal forest stands. The major factors that affect such dynamics are explored to assess their impact quantitatively. To conduct the analysis, we collected litter data from the Oi horizon (composed of mainly undecomposed foliage and twigs) and the Oe horizon (composed of partially decomposed foliage and twigs) in burned forest stands, as well as stand ecological and vegetational data (Huang and Schoenau, 1998). We hypothesized that (1) the properties of litter layer WSM would vary as they were impacted by the evolving time since fire, environmental conditions, and biotic factor; and (2) the WSM properties of the Oi and Oe horizons would react differently to spatiotemporal changes in the post-fire boreal forest. We expected that WSM changes in the litter layer after the fire disturbance would possess certain spatiotemporal patterns and that such patterns would be related to biotic factors.

\section{Materials And Methods}

\subsection{Study region}

Field data were collected from 25 sites in 11 unburned and burned stands of natural larch, Larix gmelinii (Rupr.) Kuzen., from the Greater Khingan Range area (Fu et al., 2018). The 25 sites were scattered across an area bounded by $51^{\circ} 21^{\prime}-52^{\circ} 45^{\prime} \mathrm{N}$ and $123^{\circ} 27^{\prime}-124^{\circ} 52^{\prime} \mathrm{E}$, located within the natural boreal deciduous coniferous forests in the Greater Khingan Mountains (Brandt et al., 2013). The study area has a terrestrial monsoon climate with long and cold winters. The topography of this region is characterized by small, gently sloping uplands $\left(0-30^{\circ}\right)$ and wide valleys (Kong et al., 2019). In terms of administrative management, the sites are located in Tahe County, in the northern region of the Heilongjiang province, in China (see Fig. 1). According to the China Meteorological Data Service Center, this boreal region has a cold, subhumid continental climate, with average annual precipitation of 476.3 mm, an annual average barometric pressure of $969.9 \mathrm{hPa}$, an average annual temperature of $-2.2^{\circ} \mathrm{C}$, and average annual relative humidity of $67 \%$. The frost-free period in Tahe County is 133 days, the average annual wind speed is $2.7 \mathrm{~m} / \mathrm{s}$, and the prevailing wind direction is northwest $\left(315^{\circ}\right)$. The forests in Tahe County have thick $\mathrm{Oi}$ and Oe horizons, and the main dominant species are Larix gmelinii, Pinus sylvestris var. mongolica, and Pinus pumila, late-top species that occupy moister and cooler sites.

\subsection{Data preparation}

In 2017, we selected a chronosequence of historically burned areas in Tahe by visually overlaying maps of burned-area distribution and historical fire occurrence records to identify larch stands with a burned history. Burned-area maps of historical fires for Tahe exist for as early as the 1980s. We selected the candidate study areas based on their current tree species composition, the presence of fire scars on the landscape, and the proximity to road access. We conducted a field survey that considered fire history, geodetic coordinates, slope gradient, slope aspect, slope position, and altitude to locate 25 sites in the study area. We then set up a $20 \mathrm{~m} \times 20 \mathrm{~m}$ sample plot in each site. At each sample plot, we measured all dominant trees that had a diameter at breast height (DBH) of $\geq 3 \mathrm{~cm}$, we collected six litter samples from three randomly selected $0.5 \mathrm{~m} \times 0.5 \mathrm{~m}$ litter quadrats. In August 2017 , we collected a total of 150 litter samples: 3 Oi horizon samples and 3 Oe horizon samples per plot. Coarse materials in the litter samples-such as woody debris, dead insects, and gravelwere removed, and the samples were mixed to ensure homogeneity. We stored the samples in a $-20^{\circ} \mathrm{C}$ freezer and transported them to a laboratory to await analysis. In the laboratory, we oven dried all samples at $60^{\circ} \mathrm{C}$ to a constant weight. The litter samples were then coarsely ground and screened ( $0.025-2.0 \mathrm{~mm}$ retained), while WSOC and WSN concentrations were determined on an extract of 1:10 litter to water (Kalbitz et al., 2003). After shaking for $12 \mathrm{~h}$, the extracting solution was centrifuged for $20 \mathrm{~min}$ at $6800 \mathrm{~g}$ then filtered to $<0.22 \mu \mathrm{m}$. We measured total organic carbon (TOC), total nitrogen (TN), pH, WSOC, and WSN in the litter. To measure the concentrations of WSOC and WSN, we used the multi N/C 2100S total N/C analyzer (Analytik Jena AG, Jena, Germany); to measure the concentrations of TOC and TN, we used the Elementar Vario EL III N/C analyzer (Elementar, Germany). We determined the pH values in the 1:10 litter-towater extracts using a calibrated $\mathrm{pH}$ meter.

\subsection{Data analysis}

Given that fires punctuate the successional cycles in boreal forests and shape the characteristics of the litter layer, we set the time since fire of unburned stands to 60 years for comparison purposes in later analysis because the humus layer of burned stands fully recovers 60 years after a fire (Ward et al., 2014). The topographic positions of lower slopes, mid-slopes, upper slopes, and hilltops were assigned values of 1, 2, 3, and 4 correspondingly as indicators. To eliminate the interference of slope aspect in the data analysis, we converted slope aspects $\left(0^{\circ}-360^{\circ}\right)$ to the range $[0,1]$ according to the following equation by Roberts and Cooper (1989):

$$
\text { transformation of slope aspect }(\text { TRASP })=\frac{1-\cos \left(\left(\frac{\pi}{180}\right)(\text { slope aspect }-30)\right)}{2}
$$

We used allometric models to calculate the component biomass (such as the biomass of foliage and twigs) for each individual tree, with the DBH as the only variable input to the models (Dong et al., 2014; Dong et al., 2015). Table 1 lists basic site conditions such as the time since the last fire (in years), geographical 
and topographic information, and tree mensuration summaries. Table 2 gives preliminary statistics on the biotic and abiotic variables from the Oi and Oe layers.

We conducted a paired t-test and Spearman's correlation to determine if there were statistically significant differences or correlations between the variables of WSOC concentration, WSN concentration, and WSOC-to-WSN ratio in the Oi and Oe layers. We also used three statistical methods to analyze the data: variance partition (VP), redundancy analysis (RDA), and the structural equation model (SEM). The VP method (Borcard et al., 1992) is often used in ecological data analysis and modeling because it partitions the explanatory power of the explanatory variable matrix in relation to the response variable. In this study, WSOC concentration, WSN concentration, and WSOC-WSN ratio were treated separately as the response variables, and the time since fire, environmental variables, and litter variables constituted the explanatory variable matrix.

RDA is a statistical ordination method that models the effect of explanatory variable $X$ on response variable $Y$, and $X$ and $Y$ are usually matrices (e.g., Legendre and Legendre, 1998). In RDA, the ordination of response variable $Y$ is constrained in such a way that the resulting ordination vectors are linear combinations of the variables in $X$. In this study, we grouped WSOC and WSN concentrations and WSOC-WSN ratio as the response matrix $Y$ and the time since fire, environmental variables, and litter variables as the explanatory matrix $X$. The results of the RDA on our $Y$ and $X$ matrices were a series of biplots of WSM scores and environmental and litter variables scores that demonstrate the relationships between $Y$ and $X$. Specifically, the biplots show how each type of WSM is associated with the explanatory variables and how each of the variables in the matrix $X$ affects WSM for the Oi and Oe layers.

The SEM is a multivariate statistical analysis technique used to analyze structural relationships. This technique combines factor analysis and multiple regression analysis, and it is used to analyze the structural relationship between measured variables and latent constructs (Bollen, 1989). In our data, the types of WSM were treated as measured variables, and the time since fire, the environmental variables, and the litter variables were regarded as latent constructs. We used SEM to explore the main factors that affect litter layer WSM and to assess how the variables were affected by the different factors. To use the SEM model, we first conducted a principal component analysis (PCA) of the two data groups-biotic and abiotic-individually to reduce the dimensionality of the data (Wallingford and Sorte, 2019). We found that the first two principal components accounted for $71 \%$ and $71 \%$, and $79 \%$ of total variances in the three data groups, respectively (Table 4); therefore, in the SEM analyses, we used the standardized values of WSOC and WSN and the factor loadings of the first two principal components of each group. The two principal components were designated aPC and bPC for the abiotic and biotic data groups, respectively. We used the lavaan package (Rosseel, 2012) in the R environment to run the SEMs.

\section{Results}

\subsection{WSM dynamics influenced by the time since fire and tree biomass}

In general, WSOC and WSN concentration dynamics in the Oi and Oe layers in the post-fire chronosequence exhibited similar patterns (Fig. 2). WSOC and WSN concentrations in the post-fire litter layer were lower than the concentrations in unburned stands. The concentrations decreased significantly after a fire, then gradually increased to previous levels. Post-fire WSOC and WSN concentrations in the Oi layer were higher than those in the Oe layer regardless of the time since fire. Although WSOC and WSN concentrations in the two layers were significantly different $(p<0.001)$, they were significantly and positively correlated. Neither a significant difference nor a significant correlation existed in the WSOC-WSN ratios between the two layers (Table 4).

Over time, the WSOC and WSN concentrations and the WSOC-WSN ratio in the litter layer of post-fire larch stands were gradually restored to pre-fire levels. The restoration was achieved through either concentration/ratio increase or concentration/ratio decrease as time passed after a fire. We noted significant differences between the burned and unburned layers even 27 years after a fire. It should be pointed out that the changes as shown by plots a, b, and $\mathrm{c}$ in Fig. 2 for 2 and 7 years since fire were faster than those for the longer time since fire. The ash generated by a fire may still have been playing an active role in the post-fire stands at 2 years, 5 years, and 7 years.

The post-fire stands also differed widely in tree biomass (Table 1). On the study sites where the time since fire was 7 years, we found that the tree biomass was the lowest and the altitude was the highest, while the WSOC and WSN concentrations and WSOC-WSN ratio changed drastically (Table 1). This is an important reason for our hypothesis that tree biomass and altitude affect the WSM properties in the litter layer of post-fire boreal forests. We used interpolation to generate surface plots for the WSOC and WSN concentrations and WSOC-WSN ratio in the Oi and Oe layers, using the time since fire and biomass as predictor variables (Fig. 3). (We used the software Origin 2018 to interpolate the data; see https://www.originlab.com/2018.) The interpolated concentration and ratio surfaces of the Oi and Oe layers showed different spatial patterns. For the Oi layer, the time since fire was positively correlated with the WSOC and WSN concentrations, while tree biomass had a single-mode relationship with the concentrations over large time spans, such as 30 years. No obvious patterns could be observed from the interpolated concentration surfaces for the Oe layer, suggesting the correlations between the concentrations and time span / biomass for this layer were much weaker than those for the Oi layer. In both the Oi and Oe layers, tree biomass had both positive and negative correlations with both WSOC and WSN concentrations; however, the time since fire was positively correlated with WSOC and WSN. We also noted that the dynamics of the WSOC-WSN ratios varied with different values of other variables, which made the interpolated results potentially more difficult to interpret. The impact of tree biomass on litter WSM properties appeared to be more complicated than the impact of the time since fire; this difference may presumably be attributed to variant site conditions, as tree biomass is closely related to the potential productivity of a site.

WSOC and WSN in both the Oi and Oe layers had almost the same dynamics. This phenomenon was due to the performance of the WSM carbon-nitrogen coupling in the layers, implying that the organic nitrogen in the WSN was dominant. We observed that WSOC and WSN concentrations in the Oi layer were always higher than those in the Oe layer, and WSOC, WSN, and WSOC-WSN ratios in the Oi layer showed greater variation than those in the Oe layer. Therefore, WSOC, WSN, and WSOC-WSN ratios in the Oi layer appeared to be more sensitive to the time since fire and tree biomass than those in the Oe layer. 


\subsection{Relationships between WSM properties and the time since fire, environmental properties, and litter properties}

Table 5 contains Spearman's rank correlation coefficients $(\rho)$. We preferred Spearman's correlation because Spearman's rank correlation coefficient is a distribution-free rank statistic (Hauke and Kossowski, 2011). In general, the time since fire and environmental/litter variables were significantly correlated with the WSM variables, but the correlations varied between the Oi and Oe layers. The WSM variables were significantly and positively correlated with the time since fire and significantly and negatively correlated with the environmental variables (Table 5), indicating that in burned boreal forests, as the time since fire increases, more and more organic matter was transferred from the litter layer to the soil. In the Oe layer, the WSOC-WSN ratio was more strongly correlated with the environmental variables than in the Oi layer. WSN in the Oe layer was significantly correlated with only the slope gradient and TN, and the TOC-TN ratio was significantly correlated with only the WSOC-WSN ratio in the Oe layer. Moreover, tree biomass was significantly correlated with only the WSOC-WSN ratio in the Oe layer, which was similar to the VP results of tree biomass and the time since fire (Fig. 4). TOC showed no significant correlations with the WSM variables in either the Oi layer or the Oe layer even though it represented organic matter content. The correlations between the WSM variables and mean DBH were generally the same as the correlations between the WSM variables and average tree height, as tree height and DBH were highly and positively correlated.

We conducted the VP analysis to compare the variations in litter layer WSM as explained by the time since fire, environmental variables, and litter variables both separately and jointly. The VP results indicated that all 12 explanatory variables together explained 45.9 to $76.6 \%$ of the variation in WSM in the post-fire litter layer (Fig. 4). For WSOC and WSN, the largest portion of the variation in the Oi layer was explained by the time since fire, which was supported by the environmental variables. Litter variables explained more of the variation in the Oe layer than in the Oi layer, and the time since fire explained less of the variation in the Oe layer than in the Oi layer. The time since fire explained more of the variation in the Oi layer than in the Oe layer, and the time since fire explained less of the variation in the Oe layer than the environmental and litter variables did, meaning that the effect of the time since fire was weakening. The time since fire explained a higher proportion of the variation in WSOC and WSN than in WSOC-WSN ratio.

We selected nine variables for the Oi layer and eight variables for the Oe layer to explore their relationships with the measured values of WSM variables in burned areas (Fig. 5), using the RDA model (Legendre and Legendre, 1998). For our purposes, WSOC, WSN, and WSOC-WSN ratio were treated as response variables, and all other variables were treated as explanatory ones. The biplots of the RDA results demonstrate that the time since fire and the environmental variables played different roles in how they impacted WSM variables in the Oi and Oe layers. The time since fire was closely associated with WSOC and WSN in both the Oi and Oe layers (Fig. 5), suggesting that the time since fire was an influential factor for WSOC and WSN. For the Oi layer, the arrows for the topographic factors and the time since fire are longer than the arrows for the litter variables, suggesting that the litter variables contributed less to WSM. Nevertheless, the biplot shows that tree biomass and the litter variables contributed more to WSM in the Oe layer than in the Oi layer. The longer arrows for the topographic factors and the time since fire indicate that the contributions of space and time to WSM were relatively high in both the Oi and Oe layers and that a strong association existed between the time since fire, WSOC, and WSN in both the Oi and Oe layers (Fig. 5).

\subsection{Drivers of changes in litter WSM}

SEM is used to fit data to a model that allows for causal relationships between measured variables and latent constructs. Therefore, we used SEM to intuit the possible links between abiotic factors, biotic factors, and litter WSM properties. As shown in Fig. 6, bPC2 exerted a positive impact on WSM properties in both the Oi and Oe layers, whereas aPC1 and aPC2 exerted a negative impact on WSM properties in both layers. In these study sites, abiotic factors were not significantly correlated with biotic factors, suggesting that the abiotic factors we measured contributed little to biotic factors and that abiotic factors affected litter WSM properties through biotic factors we did not consider (e.g., microbial biomass, fungi-to-bacteria ratio). Biotic factors were more strongly and significantly correlated with litter WSM properties in the Oe layer than in the Oi layer. In contrast, abiotic factors were less correlated with litter WSM properties in the Oe layer than in the Oi layer.

\section{Discussion}

\subsection{Temporal dynamics of WSM}

Given the modern fire surveillance technologies used in forest fire management, fire occurrence time is usually reported accurately; therefore, the time since fire is a variable subject to minimum measurement errors, making it a particularly convenient metric for fire study and management. The time since fire has been used by numerous fire ecology studies, and it has been regarded as one of the key factors in some post-fire forest ecosystems (Hall et al., 2006; Mendez et al., 2015; Koster et al., 2016; Makita et al., 2016; McNamara et al., 2019). In the forest stands we sampled, we found that the time since fire was significantly and positively correlated with WSOC in the Oi and Oe layers. Recognizing the temporal trends in post-fire litter and soil properties helped us to better understand biological progress in burned areas (Ward et al., 2014; Kenny et al., 2018), but this was not comprehensive enough (Watson et al., 2012). As expected, RDA and its moderate fit to WSM properties indicated that factors additional to the time since fire were also important.

The discussion of any ecological process cannot be separated from the time scale. In burned areas, organisms and environmental factors change rapidly over time and eventually reach a steady state many years later. In the period after a fire, the litter fall gradually accumulates on various terrains and forms the substrate for decomposers. It also acts as a buffer layer and nutrient pool for the soil. Ecological processes in burned areas after a fire-such as vegetation restoration, litter layer succession, or decomposer succession-are affected by multiple ecological factors and take time to move on (Keane et al., 2004; Treseder et al., 2004; Magnan et al., 2012; Ward et al., 2014; Moffet et al., 2015; Koster et al., 2016; Zaitsev et al., 2017). In this study, the burned areas were relatively small, and the post-fire evolution of the sites took place on a relatively small spatiotemporal scale. As a result, climate effects on the WSM dynamics after a fire were limited. Our results, as depicted in Fig. 7, showed that there were significantly high correlations between the stocks of WSOC and WSN in the 
two litter layers, but the correlation coefficients were lower than for the amounts of WSOC and WSN in the soil (Hilli et al., 2008; Lindenmayer et al., 2009). This likely means that the WSN in boreal forest litter is mainly organic nitrogen (Park and Matzner, 2003; McDowell et al., 2004; Uselman et al., 2012) but contains a higher proportion of inorganic nitrogen than the WSN in the soil. Although the concentrations of WSM in the two layers were different, their composition is likely to be similar (Sjoberg et al., 2004; Stark et al., 2012). Further verification is needed.

Litter-derived WSM is an important nutrient source entering the soil, but the characterization of litter WSM was often not detailed enough in previous studies for researchers to understand WSM dynamics and processes at the molecular level (Brock et al., 2019). Because fire has remarkable impacts on litter C, N, and $P$ pools (Toberman et al., 2014), observations on the changes in concentration of $C, N$, and $P$ in post-fire litter WSM are indispensable as a reference base for future research on promoting ecological restoration in burned areas (Kalbitz et al., 2004; Lee et al., 2018).

\subsection{Effects of environmental and biotic factors on changes in WSM}

Environmental factors influence spatial patterns of WSM properties across a landscape. It has been shown that environmental factors were more important drivers of long-term, post-fire vegetation assembly and patterns of soil properties than the time since fire (Shryock et al., 2015; Kong et al., 2019). Figs. 4 and 5 also confirm the importance of the effects of environmental factors on the WSM properties of burned-area litter. Topographic position, gradient, and aspect determine solar radiation, litter moisture, and temperature, which affect chemical and biological decomposition processes and thus can play important roles in determining WSM properties (Fisk et al., 1998; Griffiths et al., 2009; Song et al., 2017). These factors affect not only the litter decomposition process (Fan et al., 2014; Trogisch et al., 2016), but also the physiological and biochemical processes of vegetation (Bovard et al., 2005; Ali et al., 2015; Wright et al., 2017; Qaderi et al., 2019). In addition, the physiological and biochemical processes of vegetation after a fire are constantly changing (Beghin et al., 2011; Markovic et al., 2015; Bär et al., 2019). Litter comes from vegetation while vegetation is affected by fire and environmental factors; these may be important ways that environmental factors and the time since fire affect WSM properties. Moreover, this can explain to some extent why abiotic factors affect the WSM properties in the Oi layer more than in the Oe layer (Fig. 6). Litter in the Oi layer is fresher and more closely related to the physiology and biochemistry of the existing vegetation, and the Oi layer microenvironment is more closely related to the abiotic factors (Chen et al., 2018). The relationship between ecological factors and vegetation response is useful in understanding litter WSM property dynamics in burned areas.

Biotic factors such as tree species (Bantle et al., 2014a; Bantle et al., 2014b; Thieme et al., 2019), biodiversity (Handa et al., 2014; Trogisch et al., 2016) (Handa et al., 2014;), and microbiome (Bray et al., 2012; Bani et al., 2018) have been shown to affect litter and litter WSM properties. Our study supports the finding that biotic factors affect litter WSM properties, although we observed only a few biotic factors. Biotic factor dynamics after a fire disturbance depend on the ability of individuals to survive fire events, of the post-fire environment to contribute to ecological succession, of survivors to contribute to biotic community succession, and of colonists to establish. The interplay of these elements results in a delicate and close link between biotic and abiotic factors in a burned area. Even though the knowledge of post-fire ecosystem responses is growing, our understanding of how these processes and ecological factors are linked or coupled and how they can be mutually activated is incomplete. The ecological succession of burned areas is a long-term process in which various ecological factors are constantly changing before reaching stability (Ruokolainen and Salo, 2006; Chang et al., 2007; Abella and Fornwalt, 2015; Clarke et al., 2015), which is determined by the synthesis of fire event, post-fire environmental, and biotic factors. Evaluating the precise relationships between these ecological factors is crucial for better understanding how fires affect the litter WSM properties and for predicting or manipulating the litter WSM properties in burned areas (Kalbitz et al., 2007; Sjoberg et al., 2004; Kalbitz et al., 2004). Therefore, continued research is needed to enhance our knowledge of the underlying ecological processes in burned areas and to better understand how forest litter responds under varying abiotic and biotic factors to global climate change and increasing wildfire events (Stephens et al., 2013; Liu et al., 2014).

\section{Conclusions}

Our study provides new insights into the ecological restoration of burned areas based on litter WSM properties in boreal larch forests. It demonstrates the relative importance of the influences of abiotic and biotic factors on litter WSM properties during the early stage of post-fire boreal larch forest succession. In summary, the concentrations of litter WSM in the Oi layer were higher than in the Oe layer, and both layers were markedly altered by wildfire, but they showed different patterns of response to ecological factors. This study suggests that the difference in litter WSM in the different layers also deserves attention when we study ecological succession in burned areas. Besides, this study demonstrates that environmental and biotic factors can be more influential than the time since fire in shaping long-term, post-fire litter WSM properties. The length of time required for litter to fully recover after a wildfire event cannot be determined precisely because the ecological recovery progress of burned areas is determined by numerous factors other than simply the time since fire. Hence, careful consideration of environmental and biotic factors will benefit the modeling of post-fire ecological restoration and the planning of litter management strategies. Of relevance to forest fire management is our finding that biotic factors play important roles in litter WSM properties in burned forests, meaning that the manipulation of biotic factors can assist the restoration of litter WSM in burned areas, thereby potentially regulating and controlling the input of soil organic matter from litter and accelerating the restoration of burned areas.

\section{Declarations}

\section{Declaration of Competing Interest}

The authors declare that they have no known competing financial interests or personal relationships that could have appeared to influence the work reported in this paper. All authors contributed to the article and approved the submitted version. 


\section{Acknowledgements}

We would like to thank Huiyan Wang and the staff of the Tahe Forestry Bureau for their continued support and sampling assistance throughout the project. This work was funded by the National Key R\&D Program of China during the 13th Five-Year Period [2017YFD0600106-2], the National Natural Science Foundation of China [31870644], and the Fundamental Research Funds for the Central Universities [2572019CP10].

\section{References}

Abella SR, Fornwalt PJ (2015) Ten years of vegetation assembly after a North American mega fire. Global Change Biol 21, 789-802. https://doi.org/10.1111/gcb.12722

Ali AA, Xu C, Rogers A, McDowell NG, Medlyn BE, Fisher RA, Wullschleger SD, Reich PB, Vrugt JA, Bauerle WL, Santiago LS, Wilson CJ (2015) Global-scale environmental control of plant photosynthetic capacity. Ecol Appl 25, 2349-2365. https://doi.org/10.1890/14-2111.1.sm

Baer A, Michaletz ST, Mayr S (2019) Fire effects on tree physiology. New Phytol 223, 1728-1741. https://doi.org/10.1111/nph.15871

Bani A, Pioli S, Ventura M, Panzacchi P, Borruso L, Tognetti R, Tonon G, Brusetti L (2018) The role of microbial community in the decomposition of leaf litter and deadwood. Appl Soil Ecol 126, 75-84. https://doi.org/10.1016/j.apsoil.2018.02.017

Bantle A, Borken W, Ellerbrock RH, Schulze ED, Weisser WW, Matzner E (2014) Quantity and quality of dissolved organic carbon released from coarse woody debris of different tree species in the early phase of decomposition. Forest Ecol Manag 329, 287-294. https://doi.org/10.1016/j.foreco.2014.06.035

Bantle A, Borken W, Matzner E (2014) Dissolved nitrogen release from coarse woody debris of different tree species in the early phase of decomposition. Forest Ecol Manag 334, 277-283. https://doi.org/10.1016/j.foreco.2014.09.015

Beghin R, Cherubini P, Battipaglia G, Siegwolf R, Saurer M, Bovio G (2011) Tree-ring growth and stable isotopes (C-13 and N-15) detect effects of wildfires on tree physiological processes in Pinus sylvestris L. Trees-Struct Funct 25, 627-636. https://doi.org/10.1007/s00468-011-0539-9

Berner LT, Beck PSA, Loranty MM, Alexander HD, Mack MC, Goetz SJ (2012) Cajander larch (Larix cajanderi) biomass distribution, fire regime and post-fire recovery in northeastern Siberia (vol 9, pg 3943, 2012). Biogeosciences 9, 4871. https://doi.org/10.5194/bg-9-4871-2012

Bodí MB, Martin DA, Balfour VN, Santín C, Doerr SH, Pereira P, Cerdà A, Mataix-Solera J (2014) Wildland fire ash: Production, composition and eco-hydrogeomorphic effects. Earth-Sci Rev 130, 103-127. https://doi.org/https://doi.org/10.1016/j.earscirev.2013.12.007

Bovard BD, Curtis PS, Vogel CS, Su HB, Schmid HP (2005) Environmental controls on sap flow in a northern hardwood forest. Tree Physiol 25, 31-38. https://doi.org/10.1093/treephys/25.1.31

Brandt JP, Flannigan MD, Maynard DG, Thompson ID, Volney WJA (2013) An introduction to Canada's boreal zone: ecosystem processes, health, sustainability, and environmental issues INTRODUCTION. Environ Rev 21, 207-226. https://doi.org/10.1139/er-2013-0040

Bray SR, Kitajima K, Mack MC (2012) Temporal dynamics of microbial communities on decomposing leaf litter of 10 plant species in relation to decomposition rate. Soil Biol Biochem 49, 30-37. https://doi.org/10.1016/j.soilbio.2012.02.009

Brock O, Helmus R, Kalbitz K, Jansen B (2019) Non-target screening of leaf litter-derived dissolved organic matter using liquid chromatography coupled to high-resolution mass spectrometry (LC-QTOF-MS). Eur J Soil Sci. https://doi.org/10.1111/ejss.12894

Chang Y, He HS, Bishop I, Hu Y, Bu R, Xu C, Li X (2007) Long-term forest landscape responses to fire exclusion in the Great Xing'an Mountains, China. Int J Wildland Fire 16, 34-44. https://doi.org/10.1071/WF05093

Chen Y, Liu Y, Zhang J, Yang W, He R, Deng C (2018) Microclimate exerts greater control over litter decomposition and enzyme activity than litter quality in an alpine forest-tundra ecotone. Sci Rep-Uk 8. https://doi.org/10.1038/s41598-018-33186-4

Clarke PJ, Keith DA, Vincent BE, Letten AD (2015) Post-grazing and post-fire vegetation dynamics: long-term changes inmountain bogs reveal community resilience. J Veg Sci 26, 278-290. https://doi.org/10.1111/jvs.12239

Coleman TW, Meeker JR, Clarke SR, Rieske LK (2008) The suppression of Dendroctonus frontalis and subsequent wildfire have an impact on forest stand dynamics. Appl Veg Sci 11, 231-248. https://doi.org/10.3170/2008-7-18362

Dong L, Zhang L, Li F (2014) A compatible system of biomass equations for three conifer species in Northeast, China. Forest Ecol Manag $329,306-317$. https://doi.org/10.1016/j.foreco.2014.05.050

Dong L, Zhang L, Li F (2015) Developing additive systems of biomass equations for nine hardwood species in Northeast China. Trees-Struct Funct 29, 11491163. https://doi.org/10.1007/s00468-015-1196-1

Fan J, Zhang X, Lui X, Yan Y, Wang X (2014) Leaf Litter Decomposition in Three Subalpine Forests along an Elevation Gradient in Tibet. Pol J Environ Stud 23, $1137-1146$. 
Fisk MC, Schmidt SK, Seastedt ATR (1998) TOPOGRAPHIC PATTERNS OF ABOVE- AND BELOWGROUND PRODUCTION AND NITROGEN CYCLING IN ALPINE TUNDRA. Ecology 79, 2253-2266.

Flannigan M, Stocks B, Turetsky M, Wotton M (2009a) Impacts of climate change on fire activity and fire management in the circumboreal forest. Global Change Biol 15, 549-560. https://doi.org/10.1111/j.1365-2486.2008.01660.x

Flannigan M, Stocks B, Turetsky M, Wotton M (2009b) Impacts of climate change on fire activity and fire management in the circumboreal forest. Global Change Biol 15, 549-560. https://doi.org/10.1111/j.1365-2486.2008.01660.x

Froberg M, Berggren D, Bergkvist B, Bryant C, Knicker H (2003) Contributions of Oi, Oe and Oa horizons to dissolved organic matter in forest floor leachates. Geoderma 113, 311-322. https://doi.org/10.1016/S0016-7061(02)00367-1

Froberg M, Kleja DB, Hagedorn F (2007) The contribution of fresh litter to dissolved organic carbon leached from a coniferous forest floor. Eur J Soil Sci 58, 108-114. https://doi.org/10.1111/j.1365-2389.2006.00812.x

Fu Y, He HS, Zhao J, Larsen DR, Zhang H, Sunde MG, Duan S (2018) Climate and Spring Phenology Effects on Autumn Phenology in the Greater Khingan Mountains, Northeastern China. Remote Sens-Basel 10, 449. https://doi.org/10.3390/rs10030449

Goulden ML, McMillan AMS, Winston GC, Rocha AV, Manies KL, Harden JW, Bond-Lamberty BP (2011) Patterns of NPP, GPP, respiration, and NEP during boreal forest succession. Global Change Biol 17, 855-871. https://doi.org/10.1111/j.1365-2486.2010.02274.x

Griffiths RP, Madritch MD, Swanson AK (2009) The effects of topography on forest soil characteristics in the Oregon Cascade Mountains (USA): Implications for the effects of climate change on soil properties. Forest Ecol Manag 257, 1-7. https://doi.org/10.1016/j.foreco.2008.08.010

Hall SA, Burke IC, Hobbs NT (2006) Litter and dead wood dynamics in ponderosa pine forests along a 160-year chronosequence. Ecol Appl 16, $2344-2355$. https://doi.org/10.1890/1051-0761(2006)016[2344:LADWDI]2.0.CO;2

Handa IT, Aerts R, Berendse F, Berg MP, Bruder A, Butenschoen O, Chauvet E, Gessner MO, Jabiol J, Makkonen M, McKie BG, Malmqvist B, Peeters ETHM, Scheu S, Schmid B, van Ruijven J, Vos VCA, Hättenschwiler S (2014) Consequences of biodiversity loss for litter decomposition across biomes. Nature $509,218$.

Hart SC, DeLuca TH, Newman GS, MacKenzie MD, Boyle SI (2005) Post-fire vegetative dynamics as drivers of microbial community structure and function in forest soils. Forest Ecol Manag 220, 166-184. https://doi.org/10.1016/j.foreco.2005.08.012

Hilli S, Stark S, Derome J (2008) Water-extractable organic compounds in different components of the litter layer of boreal coniferous forest soils along a climatic gradient. Boreal Environ Res 13B, 92-106.

Huang WZ, Schoenau JJ (1998) Fluxes of water-soluble nitrogen and phosphorus in the forest floor and surface mineral soil of a boreal aspen stand. Geoderma 81, 251-264. https://doi.org/https://doi.org/10.1016/S0016-7061(97)00092-X

Kalbitz K, Glaser B, Bol R (2004a) Clear-cutting of a Norway spruce stand: implications for controls on the dynamics of dissolved organic matter in the forest floor. Eur J Soil Sci 55, 401-413. https://doi.org/10.1111/j.1351-0754.2004.00609.x

Kalbitz K, Glaser B, Bol R (2004b) Clear-cutting of a Norway spruce stand: implications for controls on the dynamics of dissolved organic matter in the forest floor. Eur J Soil Sci 55, 401-413. https://doi.org/10.1111/j.1351-0754.2004.00609.x

Kalbitz K, Meyer A, Yang R, Gerstberger P (2007) Response of dissolved organic matter in the forest floor to long-term manipulation of litter and throughfall inputs. Biogeochemistry 86, 301-318. https://doi.org/10.1007/s10533-007-9161-8

Kalbitz K, Schmerwitz J, Schwesig D, Matzner E (2003) Biodegradation of soil-derived dissolved organic matter as related to its properties. Geoderma 113, 273291. https://doi.org/10.1016/S0016-7061(02)00365-8

Keane RE, Cary GJ, Davies ID, Flannigan MD, Gardner RH, Lavorel S, Lenihan JM, Li C, Rupp TS (2004) A classification of landscape fire succession models: spatial simulations of fire and vegetation dynamics. Ecol Model 179, 3-27. https://doi.org/10.1016/j.ecolmodel.2004.03.015

Kenny SA, Bennett AF, Clarke MF, Morgan JW (2018) Time-since-fire and climate interact to affect the structural recovery of an Australian semi-arid plant community. Austral Ecol 43, 456-469. https://doi.org/10.1111/aec.12582

Kong J, Yang J, Cai W (2019) Topography controls post-fire changes in soil properties in a Chinese boreal forest. Sci Total Environ 651, $2662-2670$. https://doi.org/10.1016/j.scitotenv.2018.10.164

Koster K, Berninger F, Heinonsalo J, Linden A, Koster E, Ilvesniemi H, Pumpanen J (2016) The long-term impact of low-intensity surface fires on litter decomposition and enzyme activities in boreal coniferous forests. Int J Wildland Fire 25, 618. https://doi.org/10.1071/WF14217_CO

Lee M, Park J, Matzner E (2018) Sustained production of dissolved organic carbon and nitrogen in forest floors during continuous leaching. Geoderma 310, 163-169. https://doi.org/10.1016/j.geoderma.2017.07.027 
Lindenmayer DB, MacGregor C, Wood JT, Cunningham RB, Crane M, Michael D, Montague-Drake R, Brown D, Fortescue M, Dexter N, Hudson M, Gill AM (2009) What factors influence rapid post-fire site re-occupancy? A case study of the endangered Eastern Bristlebird in eastern Australia. Int J Wildland Fire 18, 84-95. https://doi.org/10.1071/WF07048

Liu Y, Goodrick S, Heilman W (2014) Wildland fire emissions, carbon, and climate: Wildfire-climate interactions. Forest Ecol Manag 317, 80-96. https://doi.org/10.1016/j.foreco.2013.02.020

Magnan G, Lavoie M, Payette S (2012) Impact of fire on long-term vegetation dynamics of ombrotrophic peatlands in northwestern Quebec, Canada. Quaternary Res 77, 110-121. https://doi.org/10.1016/j.yqres.2011.10.006

Makita N, Pumpanen J, Koster K, Berninger F (2016) Changes in very fine root respiration and morphology with time since last fire in a boreal forest. Plant Soil 402, 303-316. https://doi.org/10.1007/s11104-016-2801-9

McDowell WH, Magill AH, Aitkenhead-Peterson JA, Aber JD, Merriam JL, Kaushal SS (2004) Effects of chronic nitrogen amendment on dissolved organic matter and inorganic nitrogen in soil solution. Forest Ecol Manag 196, 29-41. https://doi.org/10.1016/j.foreco.2004.03.010

McNamara BA, Kane JM, Greene DF (2019) Post-fire fuel succession in a rare California, USA, closed-cone conifer. Fire Ecol 15. https://doi.org/10.1186/s42408-019-0059-3

Mendez J, Morales G, de Nascimento L, Otto R, Gallardo A, Maria Fernandez-Palacios J (2015) Understanding long-term post-fire regeneration of a fireresistant pine species. Ann Forest Sci 72, 609-619. https://doi.org/10.1007/s13595-015-0482-9

Moffet CA, Taylor JB, Booth DT (2015) Postfire shrub cover dynamics: A 70-year fire chronosequence in mountain big sagebrush communities. J Arid Environ 114, 116-123. https://doi.org/10.1016/j.jaridenv.2014.12.005

MARKOVIC MS, Ilic BS, Miladinovic DL, Stamenkovic SM, Trajkovic R, STANKOV-JOVANOVIC VP, Djelic GT (2015) Activity of a catalase enzyme in plants from the burned areas of the Vidlic mountain beech forest. Oxidation Communications 38, 860-868.

Neff JC, Asner GP (2001) Dissolved Organic Carbon in Terrestrial Ecosystems: Synthesis and a Model. Ecosystems 4, $29-48$. https://doi.org/10.1007/s100210000058

Park JH, Matzner E (2003) Controls on the release of dissolved organic carbon and nitrogen from a deciduous forest floor investigated by manipulations of aboveground litter inputs and water flux. Biogeochemistry 66, 265-286. https://doi.org/10.1023/B:BIOG.0000005341.19412.7b

Preston CM, Bhatti JS, Flanagan LB, Norris C (2006) Stocks, chemistry, and sensitivity to climate change of dead organic matter along the Canadian boreal forest transect case study. Climatic Change 74, 223-251. https://doi.org/10.1007/s10584-006-0466-8

Qaderi MM, Martel AB, Dixon SL (2019) Environmental Factors Influence Plant Vascular System and Water Regulation. PLANTS-BASEL 8, 65. https://doi.org/10.3390/plants8030065

Roberts DW, Cooper SV 1989 Concepts and techniques of vegetation mapping. General Technical Report INT-US Department of Agriculture, Forest Service, Intermountain Research Station, USA. pp. 90-96.

Rosseel Y (2012) lavaan: An R Package for Structural Equation Modeling. J Stat Softw 48, 1-36.

Rumpel C (2019) Soils linked to climate change. Nature 572, 442-443. https://doi.org/10.1038/d41586-019-02450-6

Ruokolainen L, Salo K (2006) The succession of boreal forest vegetation during ten years after slash-burning in Koli National Park, eastern Finland. Ann Bot Fenn 43, 363-378.

Santin C, Doerr SH, Merino A, Bryant R, Loader NJ (2016) Forest floor chemical transformations in a boreal forest fire and their correlations with temperature and heating duration. Geoderma 264, 71-80. https://doi.org/10.1016/j.geoderma.2015.09.021

Sayer EJ (2006) Using experimental manipulation to assess the roles of leaf litter in the functioning of forest ecosystems. Biol Rev 81, 1-31. https://doi.org/10.1017/S1464793105006846

Scharlemann JPW, Tanner EVJ, Hiederer R, Kapos V (2014) Global soil carbon: understanding and managing the largest terrestrial carbon pool. Carbon Manag 5, 81-91. https://doi.org/10.4155/CMT.13.77

Schulze ED, Wirth C, Mollicone D, von Luepke N, Ziegler W, Achard F, Mund M, Prokushkin A, Scherbina S (2012) Factors promoting larch dominance in central Siberia: fire versus growth performance and implications for carbon dynamics at the boundary of evergreen and deciduous conifers. Biogeosciences $9,1405-$ 1421. https://doi.org/10.5194/bg-9-1405-2012

Shryock DF, Esque TC, Chen FC (2015) Topography and climate are more important drivers of long-term, post-fire vegetation assembly than time-since-fire in the Sonoran Desert, US. J Veg Sci 26, 1134-1147. https://doi.org/10.1111/jvs.12324 
Sjoberg G, Knicker H, Nilsson SI, Berggren D (2004) Impact of long-term N fertilization on the structural composition of spruce litter and mor humus. Soil Biol Biochem 36, 609-618. https://doi.org/10.1016/j.soilbio.2003.11.006

Song X, Wang G, Ran F, Chang R, Song C, Xiao Y (2017) Effects of topography and fire on soil CO(2)and CH4 flux in boreal forestunderlain by permafrost in northeast China. Ecol Eng 106, 35-43. https://doi.org/10.1016/j.ecoleng.2017.05.033

Stark S, Hilli S, Willfor S, Smeds Al, Reunanen M, Penttinen M, Hautajarvi R (2012) Composition of lipophilic compounds and carbohydrates in the accumulated plant litter and soil organic matter in boreal forests. Eur J Soil Sci 63, 65-74. https://doi.org/10.1111/j.1365-2389.2011.01411.x

Stephens SL, Agee JK, Fule PZ, North MP, Romme WH, Swetnam TW, Turner MG (2013) Managing Forests and Fire in Changing Climates. Science 342 , 41-42. https://doi.org/10.1126/science.1240294

Thieme L, Graeber D, Hofmann D, Bischoff S, Schwarz MT, Steffen B, Meyer U, Kaupenjohann M, Wilcke W, Michalzik B, Siemens J (2019) Dissolved organic matter characteristics of deciduous and coniferous forests with variable management: different at the source, aligned in the soil. Biogeosciences 16,1411 1432. https://doi.org/10.5194/bg-16-1411-2019

Tipping E, Froberg M, Berggren D, Mulder J, Bergkvist B (2005) DOC leaching from a coniferous forest floor: modeling a manipulation experiment. J Plant Nutr Soil Sc 168, 316-324. https://doi.org/10.1002/jpln.200421645

Toberman H, Chen C, Lewis T, Elser JJ (2014) High-frequency fire alters C : N : P stoichiometry in forest litter. Global Change Biol 20, $2321-2331$. https://doi.org/10.1111/gcb.12432

Tranvik LJ, Downing JA, Cotner JB, Loiselle SA, Striegl RG, Ballatore TJ, Dillon P, Finlay K, Fortino K, Knoll LB, Kortelainen PL, Kutser T, Larsen S, Laurion I, Leech DM, McCallister SL, McKnight DM, Melack JM, Overholt E, Porter JA, Prairie Y, Renwick WH, Roland F, Sherman BS, Schindler DW, Sobek S, Tremblay A, Vanni MJ, Verschoor AM, von Wachenfeldt E, Weyhenmeyer GA (2009) Lakes and reservoirs as regulators of carbon cycling and climate. Limnol Oceanogr 54, 2298-2314. https://doi.org/10.4319/lo.2009.54.6_part_2.2298

Treseder KK, Mack MC, Cross A (2004) Relationships among fires, fungi, and soil dynamics in Alaskan Boreal Forests. Ecol Appl 14, $1826-1838$. https://doi.org/10.1890/03-5133

Trogisch S, He J, Hector A, Scherer-Lorenzen M (2016) Impact of species diversity, stand age and environmental factors on leaf litter decomposition in subtropical forests in China. Plant Soil 400, 337-350. https://doi.org/10.1007/s11104-015-2737-5

Uselman SM, Qualls RG, Lilienfein J (2012) Quality of soluble organic C, N, and P produced by different types and species of litter: Root litter versus leaf litter. Soil Biol Biochem 54, 57-67. https://doi.org/10.1016/j.soilbio.2012.03.021

Vargas R, Allen MF, Allen EB (2008) Biomass and carbon accumulation in a fire chronosequence of a seasonally dry tropical forest. Global Change Biol 14, 109-124. https://doi.org/10.1111/j.1365-2486.2007.01462.x

Walker XJ, Baltzer JL, Cumming SG, Day NJ, Ebert C, Goetz S, Johnstone JF, Potter S, Rogers BM, Schuur EAG, Turetsky MR, Mack MC (2019) Increasing wildfires threaten historic carbon sink of boreal forest soils. Nature 572, 520-523. https://doi.org/10.1038/s41586-019-1474-y

Wallingford PD, Sorte CJB (2019) Community regulation models as a framework for direct and indirect effects of climate change on species distributions. Ecosphere 10. https://doi.org/10.1002/ecs2.2790

Ward C, Pothier D, Pare D (2014) Do Boreal Forests Need Fire Disturbance to Maintain Productivity? Ecosystems 17, $1053-1067$. https://doi.org/10.1007/s10021-014-9782-4

Watson SJ, Taylor RS, Nimmo DG, Kelly LT, Haslem A, Clarke MF, Bennett AF (2012) Effects of time since fire on birds: How informative are generalized fire response curves for conservation management? Ecol Appl 22, 685-696. https://doi.org/10.1890/11-0850.1

Wickland KP, Waldrop MP, Aiken GR, Koch JC, Jorgenson M, Striegl RG (2018) Dissolved organic carbon and nitrogen release from boreal Holocene permafrost and seasonally frozen soils of Alaska. Environ Res Lett 13, 65011. https://doi.org/10.1088/1748-9326/aac4ad

Wright IJ, Dong N, Maire V, Prentice IC, Westoby M, Diaz S, Gallagher RV, Jacobs BF, Kooyman R, Law EA, Leishman MR, Niinemets U, Reich PB, Sack L, Villar R, Wang H, Wilf P (2017) Global climatic drivers of leaf size. Science 357, 917. https://doi.org/10.1126/science.aal4760

Zaitsev AS, Gongalsky KB, Korobushkin DI, Butenko KO, Gorshkova IA, Rakhleeva AA, Saifutdinov RA, Kostina NV, Shakhab SV, Yazrikova TE (2017) Reduced functionality of soil food webs in burnt boreal forests: a case study in Central Russia. Contemp Probl Ecol 10, $277-285$.

https://doi.org/10.1134/S199542551703012X

\section{Tables}

Table 1. Description of the environmental and mensuration variables in the study sites in Tahe County 


\begin{tabular}{|c|c|c|c|c|c|c|c|c|c|c|}
\hline $\begin{array}{l}\text { Time since last } \\
\text { fire }\end{array}$ & $\begin{array}{l}\text { Sample } \\
\text { site }\end{array}$ & Longitude & Latitude & $\begin{array}{l}\text { Altitude } \\
(\mathrm{m})\end{array}$ & $\begin{array}{l}\text { Slope } \\
\text { gradient }\end{array}$ & $\begin{array}{l}\text { Slope } \\
\text { aspect }\end{array}$ & $\begin{array}{l}\text { Slope } \\
\text { position }\end{array}$ & $\begin{array}{l}\mathrm{DBH}_{1.3} \\
(\mathrm{~cm})\end{array}$ & $\begin{array}{l}\mathrm{H} \\
(\mathrm{m})\end{array}$ & $\begin{array}{l}\text { Tree biomass } \\
(\mathrm{t} / \mathrm{ha})\end{array}$ \\
\hline 27 & $1990 \mathrm{~A}$ & $124^{\circ} 41.4491^{\prime}$ & $52^{\circ} 23.0317^{\prime}$ & 450 & $4^{\circ}$ & $315^{\circ}$ & $\begin{array}{l}\text { lower } \\
\text { slope }\end{array}$ & 13.5 & 11.5 & 103.16 \\
\hline 27 & $1990 B$ & $124^{\circ} 41.4100^{\prime}$ & $52^{\circ} 23.0045^{\prime}$ & 433 & $3^{\circ}$ & $290^{\circ}$ & $\begin{array}{l}\text { lower } \\
\text { slope }\end{array}$ & 15.0 & 12.1 & 113.87 \\
\hline 27 & $1990 \mathrm{C}$ & $124^{\circ} 41.4741^{\prime}$ & $52^{\circ} 23.0025^{\prime}$ & 439 & $4^{\circ}$ & $309^{\circ}$ & mid-slope & 17.7 & 11.7 & 113.05 \\
\hline 23 & 1994A & $123^{\circ} 28.6468^{\prime}$ & $52^{\circ} 41.2323^{\prime}$ & 654 & $6^{\circ}$ & $30^{\circ}$ & mid-slope & 7.4 & 6.7 & 44.11 \\
\hline 23 & 1994B & $123^{\circ} 28.7495^{\prime}$ & $52^{\circ} 41.3019^{\prime}$ & 650 & $3^{\circ}$ & $107^{\circ}$ & $\begin{array}{l}\text { lower } \\
\text { slope }\end{array}$ & 9.2 & 7.2 & 29.95 \\
\hline 23 & $1994 C$ & $123^{\circ} 29.0710^{\prime}$ & $52^{\circ} 41.5476^{\prime}$ & 672 & $6^{\circ}$ & $116^{\circ}$ & $\begin{array}{l}\text { lower } \\
\text { slope }\end{array}$ & 11.1 & 10.0 & 117.59 \\
\hline 21 & 1996A & $123^{\circ} 56.9546^{\prime}$ & $52^{\circ} 40.4280^{\prime}$ & 473 & $2^{\circ}$ & $48^{\circ}$ & $\begin{array}{l}\text { lower } \\
\text { slope }\end{array}$ & 10.5 & 9.0 & 25.64 \\
\hline 21 & 1996B & $123^{\circ} 56.9704^{\prime}$ & $52^{\circ} 40.4283^{\prime}$ & 472 & $2^{\circ}$ & $64^{\circ}$ & $\begin{array}{l}\text { lower } \\
\text { slope }\end{array}$ & 9.9 & 9.7 & 41.51 \\
\hline 21 & $1996 C$ & $123^{\circ} 56.9185^{\prime}$ & $52^{\circ} 40.4781^{\prime}$ & 486 & $1^{\circ}$ & $34^{\circ}$ & $\begin{array}{l}\text { lower } \\
\text { slope }\end{array}$ & 11.7 & 11.8 & 94.71 \\
\hline 17 & $2000 \mathrm{~A}$ & $123^{\circ} 27.9788^{\prime}$ & $52^{\circ} 23.9531^{\prime}$ & 795 & $8^{\circ}$ & $86^{\circ}$ & $\begin{array}{l}\text { lower } \\
\text { slope }\end{array}$ & 15.8 & 13.5 & 51.43 \\
\hline 17 & $2000 B$ & $123^{\circ} 28.0076^{\prime}$ & $52^{\circ} 23.9573^{\prime}$ & 778 & $4^{\circ}$ & $62^{\circ}$ & $\begin{array}{l}\text { lower } \\
\text { slope }\end{array}$ & 13.6 & 11.6 & 61.46 \\
\hline 17 & $2000 C$ & $123^{\circ} 27.9522^{\prime}$ & $52^{\circ} 23.9895^{\prime}$ & 798 & $9^{\circ}$ & $94^{\circ}$ & mid-slope & 21.1 & 18.9 & 203.32 \\
\hline 11 & $2006 \mathrm{~A}$ & $124^{\circ} 31.0014^{\prime}$ & $52^{\circ} 20.6185^{\prime}$ & 519 & $2^{\circ}$ & $209^{\circ}$ & mid-slope & 12.3 & 13.1 & 93.54 \\
\hline 11 & $2006 B$ & $124^{\circ} 30.9904^{\prime}$ & $52^{\circ} 20.6660^{\prime}$ & 511 & $3^{\circ}$ & $212^{\circ}$ & mid-slope & 13.4 & 13.3 & 100.18 \\
\hline 11 & $2006 C$ & $124^{\circ} 30.9634^{\prime}$ & $52^{\circ} 20.6541^{\prime}$ & 518 & $1^{\circ}$ & $200^{\circ}$ & $\begin{array}{l}\text { upper } \\
\text { slope }\end{array}$ & 18.3 & 17.4 & 162.99 \\
\hline 7 & $2010 \mathrm{~A}$ & $123^{\circ} 27.7583^{\prime}$ & $52^{\circ} 19.3066^{\prime}$ & 837 & $6^{\circ}$ & $58^{\circ}$ & mid-slope & 18.3 & 15.3 & 15.57 \\
\hline 5 & $2012 A$ & $123^{\circ} 48.3676^{\prime}$ & $52^{\circ} 42.0480^{\prime}$ & 448 & $10^{\circ}$ & $258^{\circ}$ & mid-slope & 9.3 & 8.5 & 33.16 \\
\hline 5 & 2012B & $123^{\circ} 48.3642^{\prime}$ & $52^{\circ} 42.0234^{\prime}$ & 463 & $9^{\circ}$ & $282^{\circ}$ & $\begin{array}{l}\text { lower } \\
\text { slope }\end{array}$ & 8.6 & 9.2 & 93.77 \\
\hline 5 & $2012 C$ & $123^{\circ} 48.3670^{\prime}$ & $52^{\circ} 42.0038^{\prime}$ & 458 & $10^{\circ}$ & $308^{\circ}$ & $\begin{array}{l}\text { lower } \\
\text { slope }\end{array}$ & 9.3 & 9.7 & 26.99 \\
\hline 2 & $2015 A$ & $123^{\circ} 50.2778^{\prime}$ & $52^{\circ} 44.0409^{\prime}$ & 660 & $13^{\circ}$ & $123^{\circ}$ & $\begin{array}{l}\text { upper } \\
\text { slope }\end{array}$ & 26.7 & 22.3 & 163.97 \\
\hline 2 & 2015B & $123^{\circ} 50.2673^{\prime}$ & $52^{\circ} 44.0461^{\prime}$ & 669 & $7^{\circ}$ & $93^{\circ}$ & $\begin{array}{l}\text { upper } \\
\text { slope }\end{array}$ & 26.5 & 23.1 & 54.38 \\
\hline 2 & $2015 C$ & $123^{\circ} 50.2731^{\prime}$ & $52^{\circ} 44.0258^{\prime}$ & 661 & $10^{\circ}$ & $104^{\circ}$ & $\begin{array}{l}\text { upper } \\
\text { slope }\end{array}$ & 23.7 & 20.5 & 210.02 \\
\hline Unburned & $2017 A$ & $123^{\circ} 50.6435^{\prime}$ & $52^{\circ} 41.6528^{\prime}$ & 430 & $2^{\circ}$ & $15^{\circ}$ & mid-slope & 9.1 & 8.8 & 88.24 \\
\hline Unburned & 2017B & $124^{\circ} 01.7978^{\prime}$ & $52^{\circ} 39.9859^{\prime}$ & 450 & $2^{\circ}$ & $13^{\circ}$ & $\begin{array}{l}\text { lower } \\
\text { slope }\end{array}$ & 12.4 & 11.0 & 63.79 \\
\hline Unburned & $2017 C$ & $124^{\circ} 51.6650^{\prime}$ & $51^{\circ} 21.7318^{\prime}$ & 423 & $1^{\circ}$ & $115^{\circ}$ & $\begin{array}{l}\text { lower } \\
\text { slope }\end{array}$ & 13.5 & 9.8 & 126.14 \\
\hline
\end{tabular}

Table 2. Preliminary statistics on biotic and abiotic variables for the Oi and Oe layers 


\begin{tabular}{|lllll|}
\hline Variable & Minimum & Maximum & Mean & Std Dev. \\
\hline Time since fire (year) & 2 & 60 & 20.20 & 16.86 \\
\hline Slope gradient $\left(^{\circ}\right)$ & 1 & 13 & 5.12 & 3.44 \\
\hline Slope altitude $(\mathrm{m})$ & 423 & 837 & 565.88 & 134.08 \\
\hline Slope aspect $\left(^{\circ}\right)$ & 0 & 1.0 & 0.38 & 0.32 \\
\hline Slope position & 1 & 3 & 1.65 & 0.74 \\
\hline Tree biomass $(\mathrm{t} / \mathrm{ha})$ & 15.57 & 210.02 & 89.30 & 53.37 \\
\hline Litter $\mathrm{pH}$ & 3.52 & 6.54 & 4.80 & 0.52 \\
\hline TN $(\mathrm{mg} / \mathrm{g})$ & 0.46 & 1.80 & 1.22 & 0.25 \\
\hline TOC $(\mathrm{mg} / \mathrm{g})$ & 13.81 & 52.17 & 40.73 & 8.47 \\
\hline TOC : TN & 19.94 & 52.69 & 33.49 & 6.71 \\
\hline DBH $(\mathrm{cm})$ & 7.43 & 26.72 & 14.33 & 5.42 \\
\hline Height $(\mathrm{m})$ & 6.75 & 23.10 & 12.62 & 4.46 \\
\hline WSOC $(\mathrm{mg} / \mathrm{g})$ & 0.86 & 18.26 & 6.29 & 3.71 \\
\hline WSN $(\mathrm{mg} / \mathrm{g})$ & 0.02 & 0.65 & 0.23 & 0.15 \\
\hline WSOC $:$ WSN & 15.63 & 61.50 & 28.92 & 8.48 \\
\hline
\end{tabular}

Table 3. Factor loadings of PCA for SEMs of the Oi and Oe layers

\begin{tabular}{|c|c|c|c|c|c|c|c|c|c|c|c|c|c|c|}
\hline & \multicolumn{6}{|c|}{ Abiotic factors } & \multirow{2}{*}{$\begin{array}{l}\% \text { of } \\
\text { variance }\end{array}$} & \multicolumn{6}{|c|}{ Biotic factors } & \multirow{2}{*}{$\begin{array}{l}\% \text { of } \\
\text { variane }\end{array}$} \\
\hline & Component & $\begin{array}{l}\text { Time } \\
\text { since } \\
\text { fire }\end{array}$ & $\begin{array}{l}\text { Slope } \\
\text { gradient }\end{array}$ & $\begin{array}{l}\text { Slope } \\
\text { altitude }\end{array}$ & $\begin{array}{l}\text { Slope } \\
\text { aspect }\end{array}$ & $\begin{array}{l}\text { Slope } \\
\text { position }\end{array}$ & & $\begin{array}{l}\text { Tree } \\
\text { biomass }\end{array}$ & $\begin{array}{l}\text { Litter } \\
\mathrm{pH}\end{array}$ & TN & TOC & $\mathrm{DBH}_{1.3}$ & $\mathrm{H}(\mathrm{m})$ & \\
\hline \multirow{2}{*}{$\begin{array}{l}\text { Oi } \\
\text { layer }\end{array}$} & PC1 & -0.859 & 0.801 & 0.584 & 0.340 & 0.649 & 45.148 & 0.777 & 0.660 & -0.005 & -0.047 & 0.950 & 0.947 & 47.346 \\
\hline & PC2 & -0.100 & -0.181 & -0.672 & 0.867 & 0.241 & 26.081 & 0.037 & -0.155 & 0.808 & 0.871 & 0.062 & 0.063 & 24.072 \\
\hline \multirow{2}{*}{$\begin{array}{l}\text { Oe } \\
\text { layer }\end{array}$} & PC1 & -0.859 & 0.801 & 0.584 & 0.340 & 0.649 & 45.148 & 0.801 & 0.750 & 0.238 & -0.236 & 0.932 & 0.931 & 50.886 \\
\hline & $\mathrm{PC} 2$ & -0.100 & -0.181 & -0.672 & 0.867 & 0.241 & 26.081 & 0.063 & -0.161 & 0.897 & 0.918 & 0.038 & 0.041 & 28.019 \\
\hline
\end{tabular}

$D_{1.3}$ means average tree diameter measured at $1.3 \mathrm{~m}$ height; $\mathrm{H}$ is the average tree height.

Table 4. Spearman's rank correlation coefficients $(\rho)$ and paired t-test values for litter WSM properties between the Oi and Oe layers

\begin{tabular}{|lll|}
\hline & Correlation coefficient & p value of paired t-test \\
\hline WSOC & $0.445^{\star}$ & 0.000 \\
\hline WSN & $0.531^{\star *}$ & 0.000 \\
\hline WSOC : WSN & 0.208 & 0.717 \\
\hline
\end{tabular}

* Significant at the 0.05 probability level.

** Significant at the 0.01 probability level

Table 5. Spearman's rank correlation coefficients ( $\rho$ ) between selected litter properties, time since fire, and environmental variables for WSM properties measured 


\begin{tabular}{|c|c|c|c|c|c|c|c|c|c|c|c|c|c|c|}
\hline & & $\begin{array}{l}\text { Time } \\
\text { since } \\
\text { fire }\end{array}$ & \multicolumn{2}{|c|}{ Slope gradient } & \multirow{2}{*}{$\begin{array}{l}\text { Altitude } \\
-0.654^{* *}\end{array}$} & \multirow{2}{*}{\multicolumn{2}{|c|}{$\begin{array}{l}\text { Slope } \\
\text { aspect }\end{array}$}} & \multicolumn{2}{|c|}{ Tree biomass } & \multirow{2}{*}{$\begin{array}{l}\mathrm{DBH}_{1.3} \\
\mathbf{- 0 . 4 2 3 ^ { * }}\end{array}$} & \multirow[t]{2}{*}{ Height } & \multicolumn{2}{|c|}{ Litter pH } & \multirow{2}{*}{$\begin{array}{l}\mathrm{TN} \\
-0.0\end{array}$} \\
\hline $\begin{array}{l}\text { Oi } \\
\text { layer }\end{array}$ & WSOC & \multicolumn{2}{|c|}{$0.647^{* *}$} & \multirow{2}{*}{$\begin{array}{l}-0.490^{*} \\
-0.697^{* \star}\end{array}$} & & & & $-0.597^{\star \star}$ & \multirow{2}{*}{$\begin{array}{l}-0.098 \\
-0.412^{*}\end{array}$} & & & & -0.120 & \\
\hline WSN & & $0.687^{* k}$ & $-0.423^{*}$ & & & 0.010 & $-0.631^{* *}$ & 0.074 & & $-.416^{*}$ & & -0.149 & 0.133 & $-0 . C$ \\
\hline $\begin{array}{l}\text { WSOC } \\
\text { WSN }\end{array}$ & & -0.186 & 0.021 & 0.168 & & $-0.506^{* *}$ & 0.136 & -0.181 & 0.086 & 0.079 & & 0.051 & -0.337 & 0.0 \\
\hline \multirow{3}{*}{$\begin{array}{l}\text { Oe } \\
\text { layer }\end{array}$} & wSOC & \multicolumn{2}{|c|}{$0.572^{\star *}$} & $-0.461^{*}$ & $-0.494^{*}$ & \multicolumn{2}{|c|}{-0.086} & $-0.508^{\star *}$ & -0.065 & $-0.554^{\star *}$ & $-.585^{* *}$ & & $-0.402^{*}$ & $0.0:$ \\
\hline & WSN & \multicolumn{2}{|c|}{0.377} & $-0.424^{*}$ & -0.364 & \multicolumn{2}{|c|}{0.276} & -0.181 & 0.337 & -0.197 & -0.218 & & -0.143 & 0.41 \\
\hline & \multicolumn{2}{|c|}{$\begin{array}{l}\text { WSOC: } \\
\text { WSN }\end{array}$} & 0.268 & -0.071 & 0.130 & \multicolumn{2}{|c|}{$-0.568^{\star *}$} & $-.461^{*}$ & $-0.514^{\star *}$ & -0.346 & -0.328 & & $-0.502^{*}$ & -0.4 \\
\hline
\end{tabular}

$D_{1.3}$ is the average tree diameter measured at $1.3 \mathrm{~m}$ height. Height is the average tree height.

Number of samples $=75$

* Significant at the 0.05 level.

** Significant at the 0.01 level.

\section{Figures}

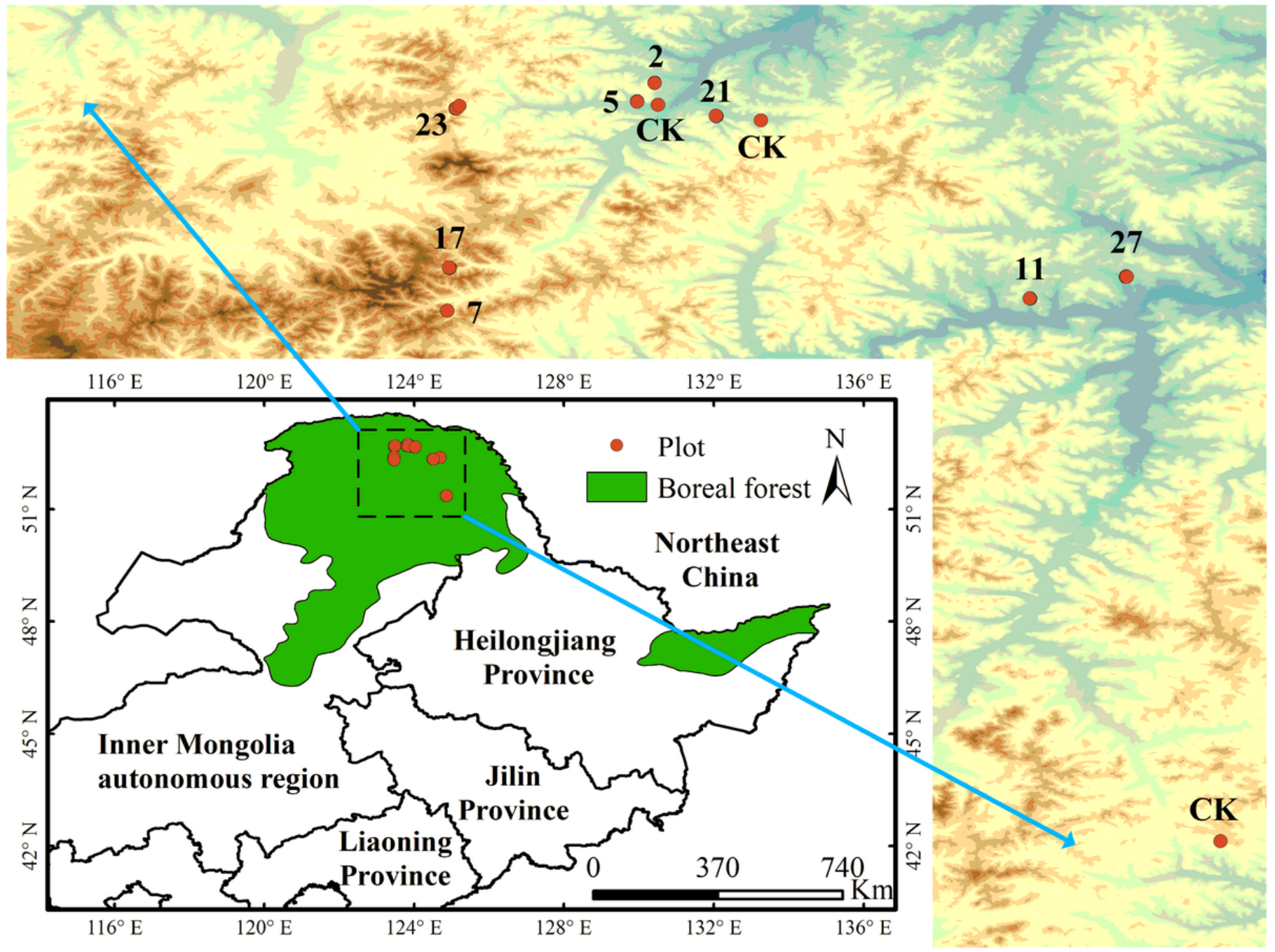

Figure 1 
Location of the study area within the boreal zone in China, and sites in the Greater Khingan Mountains that comprised the chronosequence of the time since fire. Note: The designations employed and the presentation of the material on this map do not imply the expression of any opinion whatsoever on the part of Research Square concerning the legal status of any country, territory, city or area or of its authorities, or concerning the delimitation of its frontiers or boundaries. This map has been provided by the authors.
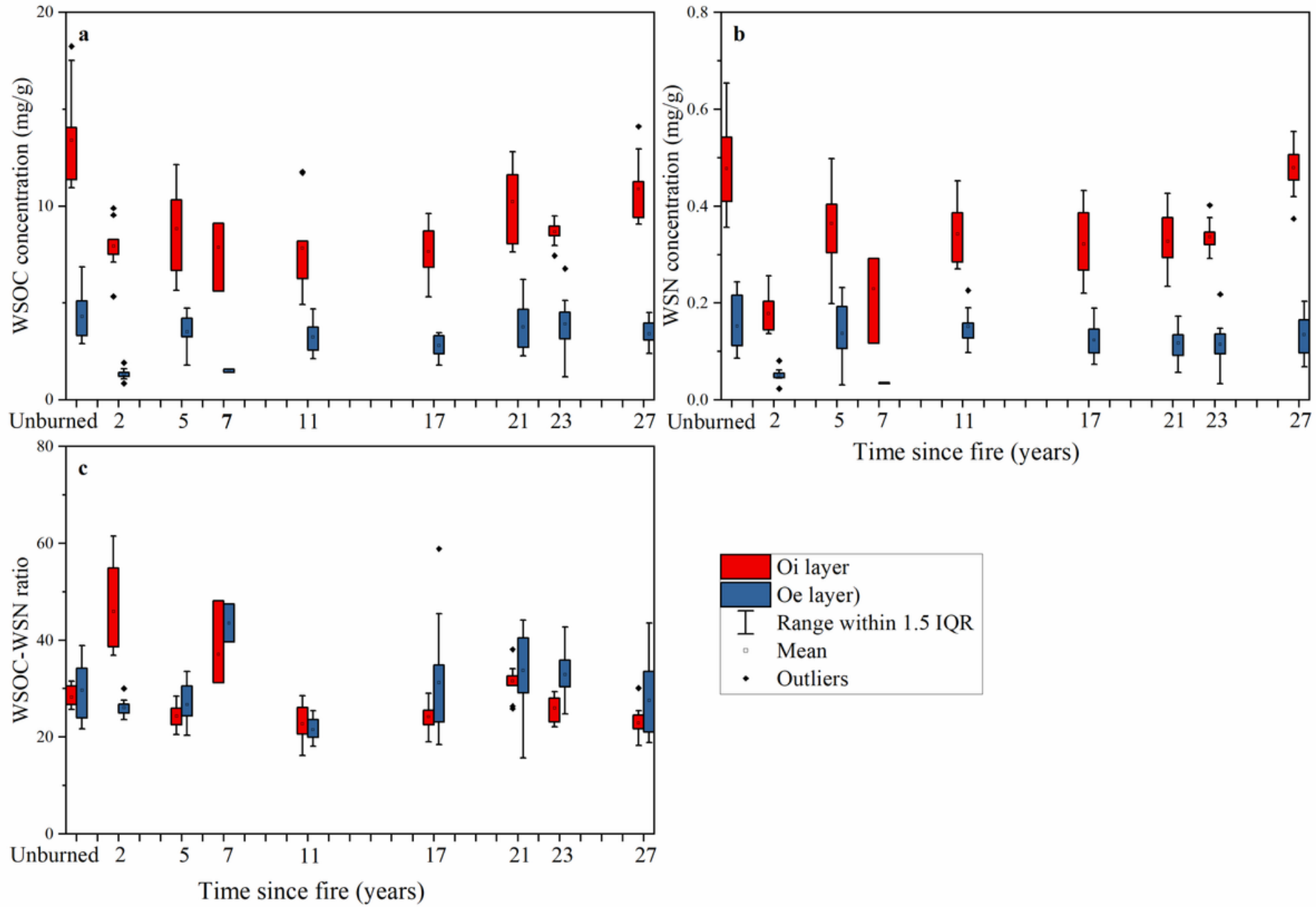

Time since fire (years)

\begin{tabular}{|l|l|}
\hline & Oi layer \\
\hline \hline & Oe layer) \\
\hline $\mathrm{I}$ & Range within 1.5 IQR \\
.$\quad$ & Mean \\
. & Outliers
\end{tabular}

Figure 2

Box plots of WSM property analyses in the Oi and Oe litter layers: (a) WSOC concentration, (b) WSN concentration, and (c) WSOC-WSN ratio. The box plots show the first quartile, outliers, mean, and third quartile of the samples, and the whiskers show the range of minimum and maximum. 

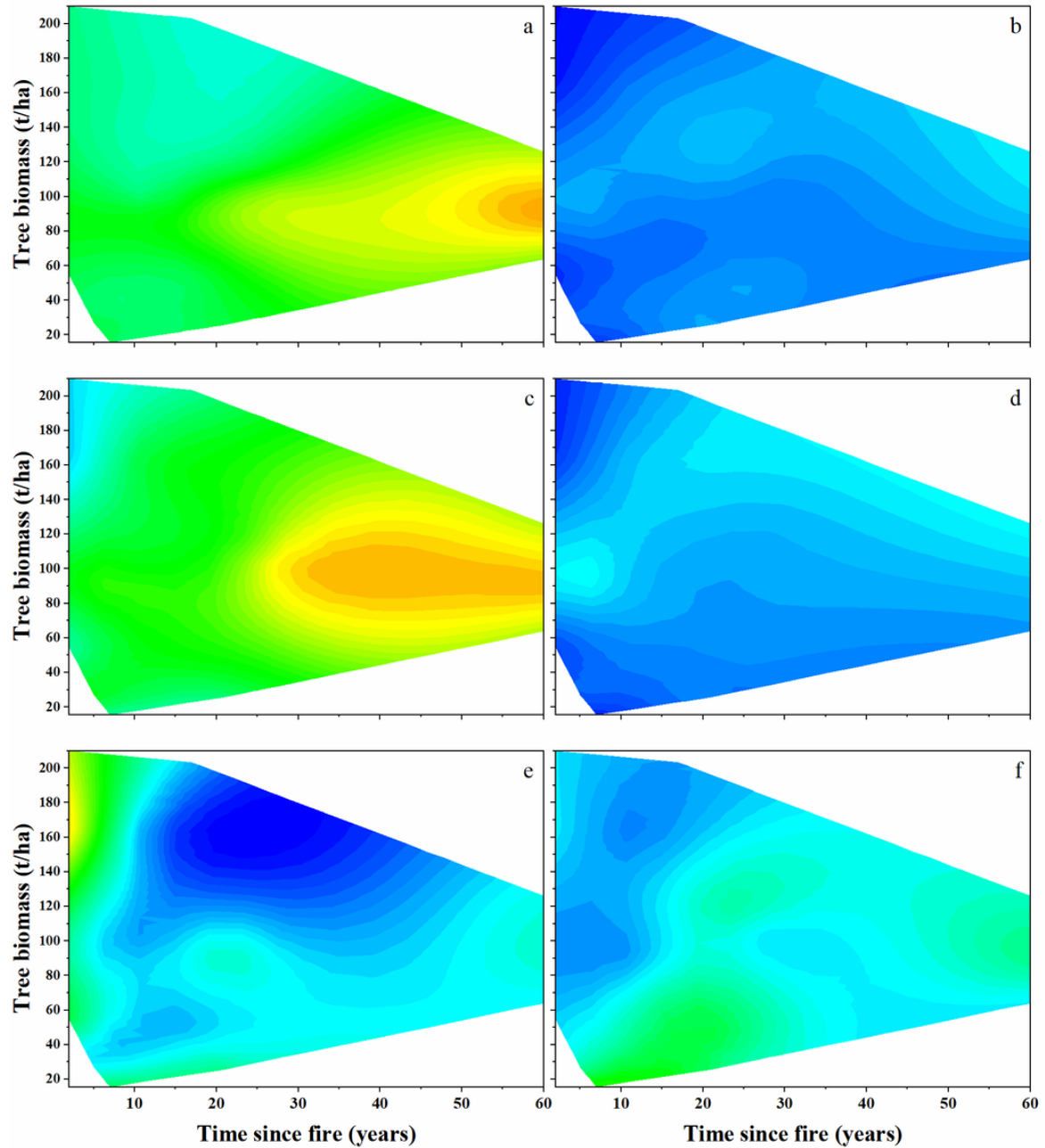

WSOC (mg/g)

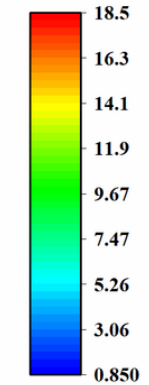

WSN (mg/g)

\section{WSN (mg/g)}

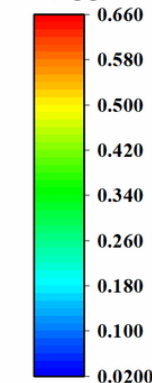

WSOC : WSN

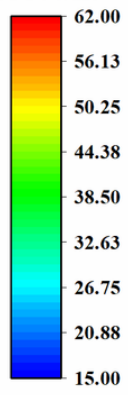

Figure 3

Contour plots of WSM property analyses in the Oi and Oe litter layers: $(a, b)$ WSOC concentration in the Oi and Oe layers, respectively; (c, d) WSN concentration in the Oi and Oe layers, respectively; and $(\mathrm{e}, \mathrm{f})$ WSOC-WSN ratio in the Oi and Oe layers, respectively. The symbols on the right side of the contour plots show the distribution of sample values. 


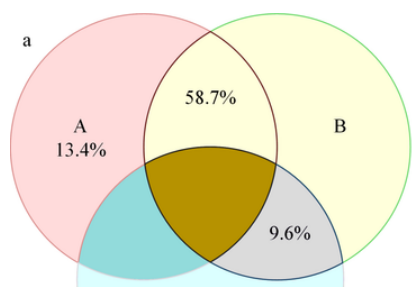

C

Residuals $=43.6 \%$

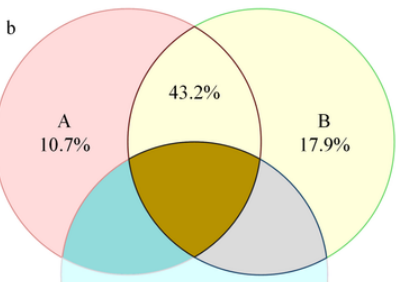

C

$9.1 \%$

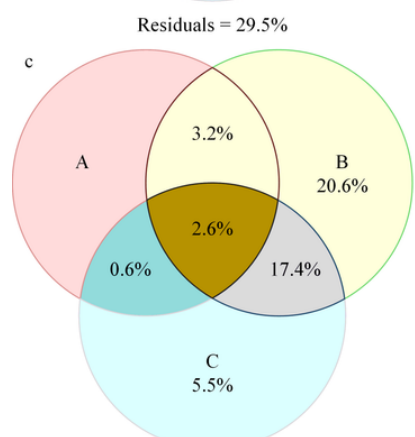

Residuals $=54.1 \%$

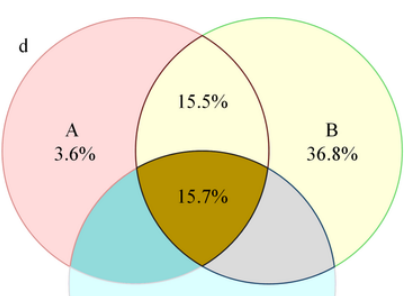

C
$8.5 \%$

Residuals $=33.2 \%$

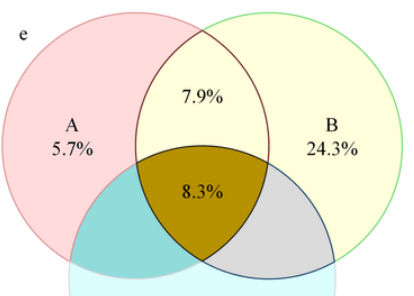

$15.5 \%$

Residuals $=51.4 \%$

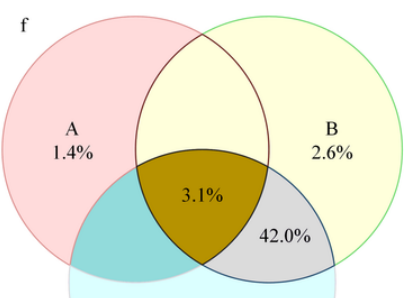

$\mathrm{C}$
$34.2 \%$

Residuals $=23.4 \%$

\section{Figure 4}

Results of variation partitioning for WSOC, WSN, and WSOC-WSN ratios in the Oi and Oe layers in terms of the fractions of variation explained: (a) WSOC concentration in the Oi layer, (b) WSN concentration in the Oi layer, (c) WSOC-WSN ratio in the Oi layer, (d) WSOC concentration in the Oe layer, (e) WSN concentration in the Oe layer, (f) WSOC-WSN ratio in the Oe layer. The variation of the WSM data matrix is explained by three groups of explanatory variables, independent or shared: (A) time since fire; (B) environmental variables, including slope gradient, altitude, slope aspect, slope position, tree biomass, DBH1.3, and average tree height; and (C) litter properties, including litter $\mathrm{pH}, \mathrm{TN}, \mathrm{TOC}$, and TOC-TN ratio. The explained variation percentages are based on adjusted R2 values. Values $<0.001$ are not shown. 

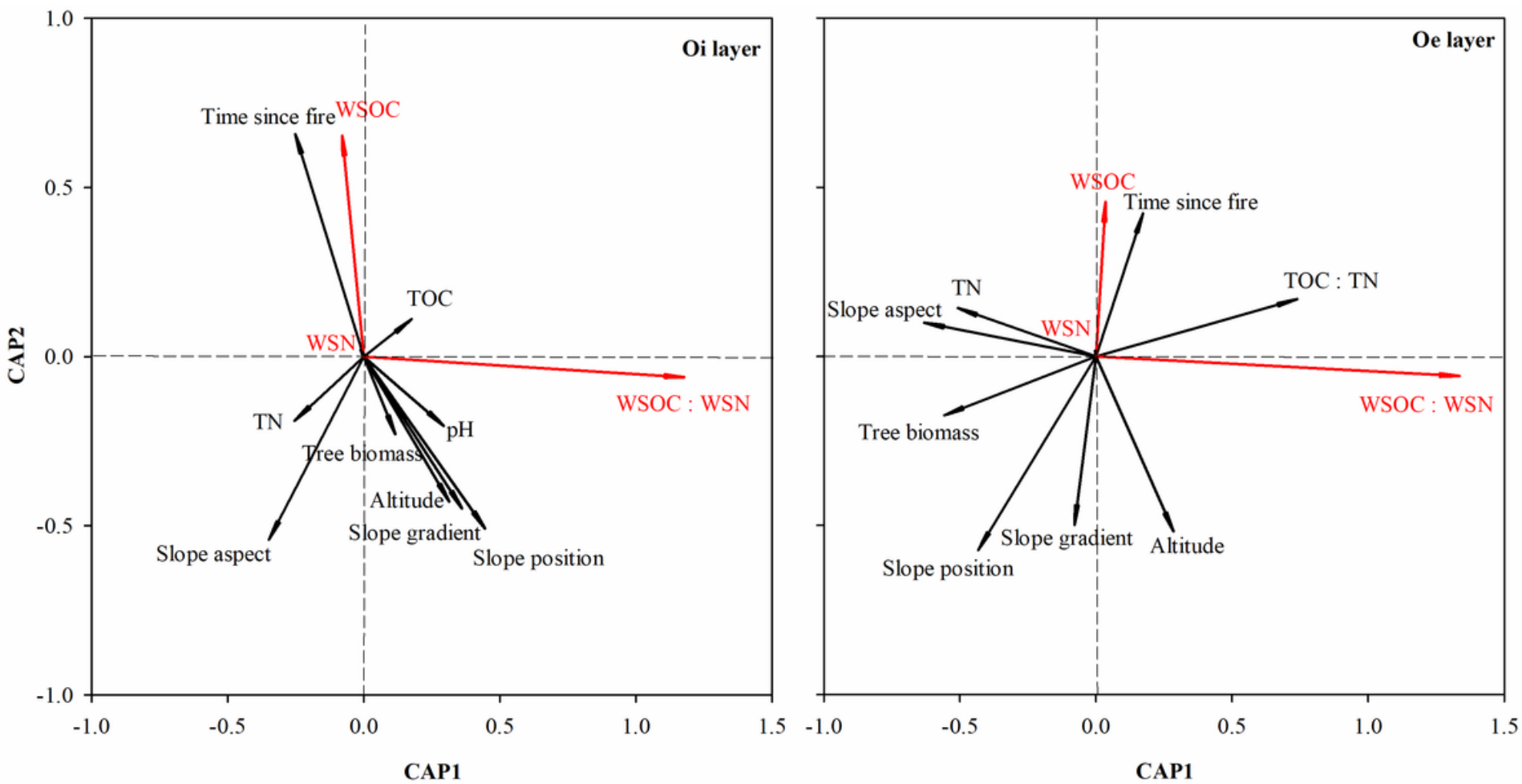

Figure 5

Biplots of RDA in the Oi and Oe layers. The black arrows represent the explanatory variables, and the red arrows represent response the variables. The WSN arrows are very short but are located in the second quadrant of each biplot. 


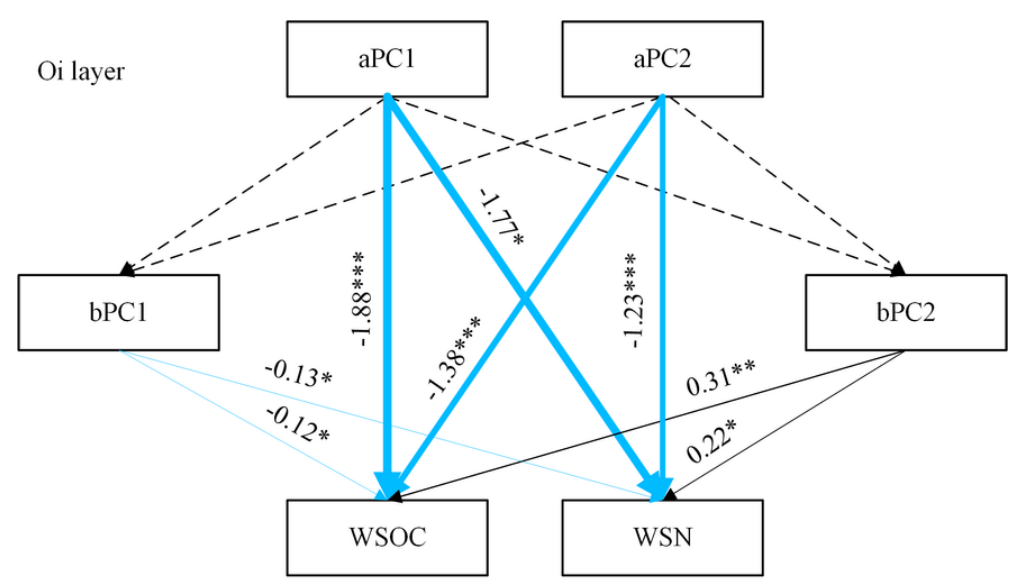

$\chi^{2}=7.979, p=0.065, \mathrm{CFI}=0.950, \mathrm{NFI}=0.948, \mathrm{GFI}=0.970, \mathrm{RMSEA}=0.035$

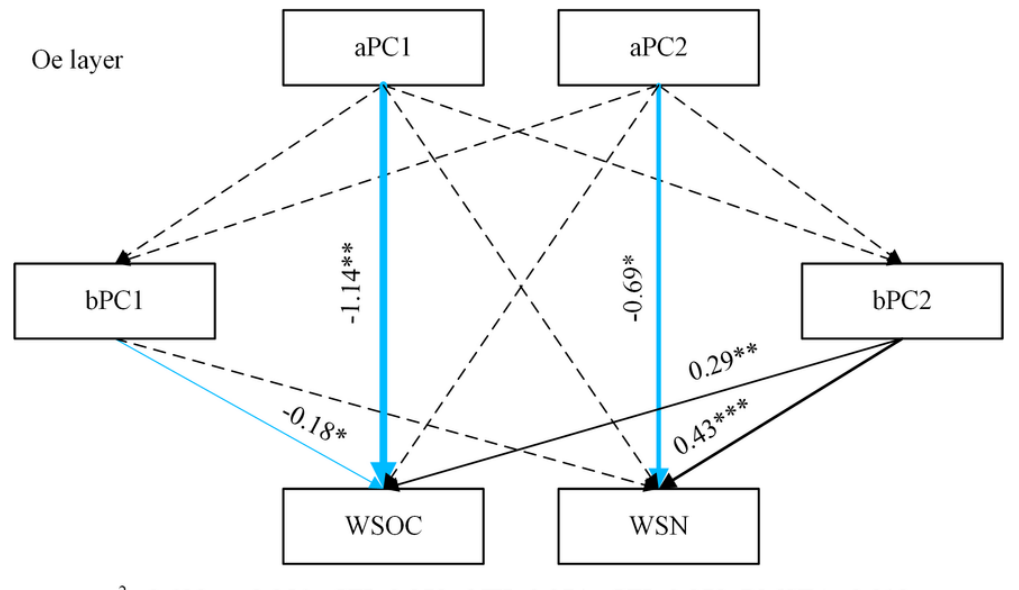

$\chi^{2}=3.639, p=0.056, \mathrm{CFI}=0.979, \mathrm{NFI}=0.974, \mathrm{GFI}=0.979, \mathrm{RMSEA}=0.019$

\section{Figure 6}

Path diagrams of path analyses in the SEM for the relationships between abiotic factors (aPC1 and aPC2), biotic factors (bPC1 and bPC2), and the standardized WSOC and WSN values in the Oi and Oe layers. Arrows represent the direction of direct effect, and the numbers along the arrows are standardized path coefficients, which indicate the strength of direct effect and the direction of relationship. Blue arrows represent negative paths, and black arrows represent positive paths. Arrow width is proportional to the strength of the path coefficient. Model fitness details are provided below the path diagrams. Solid and dotted arrows indicate significant and non-significant relationships, respectively. Significance level: * $P<0.05 ; * \star P<0.01 ; * \star * P<0.001$. 


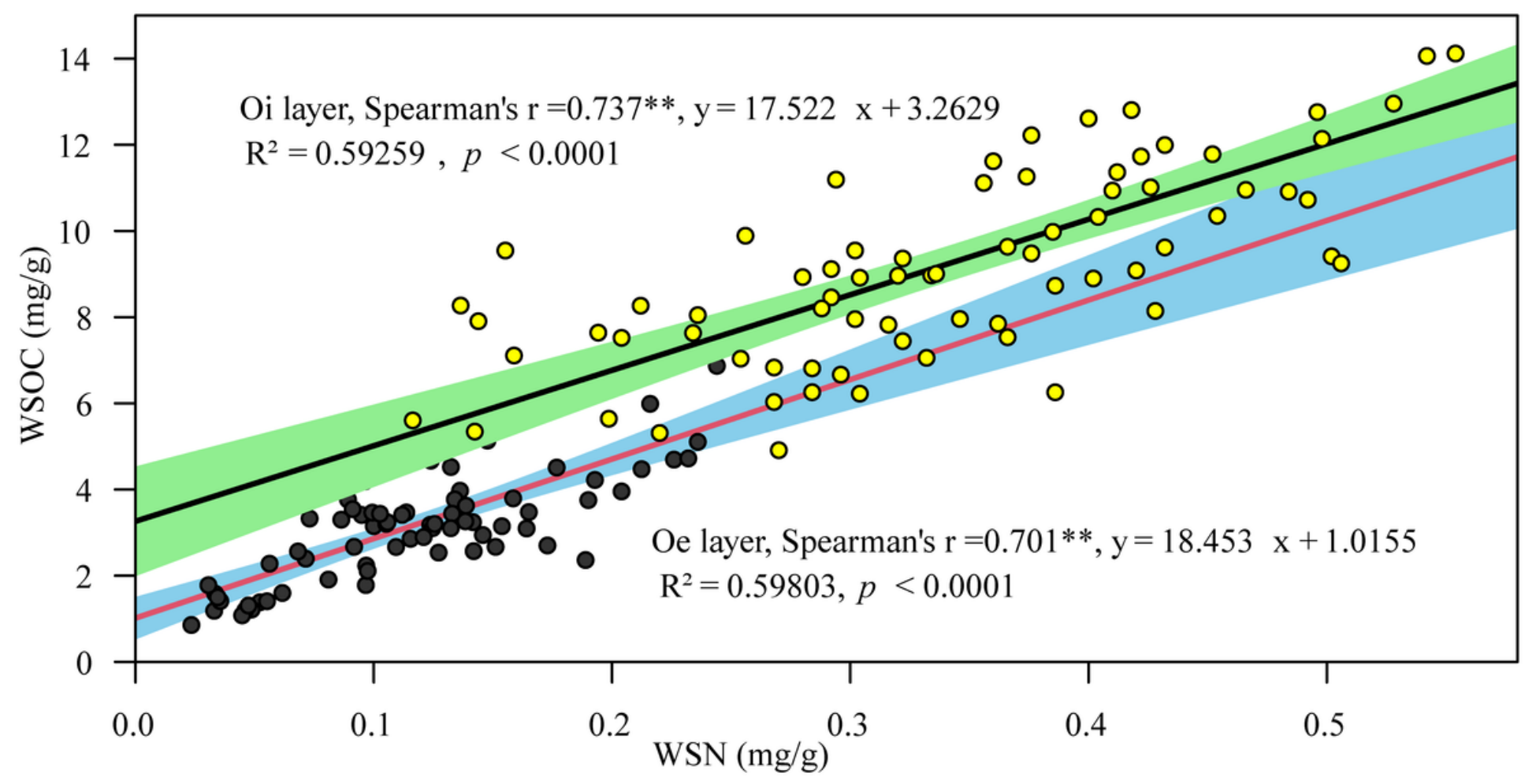

Figure 7

Linear regressions comparing the concentrations of WSOC and WSN in the Oi and Oe layers. Spearman's $r-a s$ well as y, R2, and p-are given for the best ranked $(\mathrm{DAICC}=0)$ models for the Oi and Oe layers. Shaded bands indicate $95 \%$ confidence intervals surrounding the model predictions. 